\title{
Legal Irresponsibility and Institutional Responses to Child Sex Abuse
}

\author{
Penny Crofts
}

\begin{abstract}
The current Royal Commission into Institutional Responses to Child Sexual Abuse has demonstrated serious long-term failures to prevent and adequately respond to child sexual abuse by institutions. Rather than regarding the law as a system of responsibility, this article argues that it can be read instead as organising irresponsibility, drawing upon Scott Veitch's ideas in Law and Irresponsibility. His key argument is that legal institutions operate as much to deflect responsibility for harms suffered as to acknowledge them. This article focuses on the ways in which the criminal justice system is complicit in organising irresponsibility for systemic failures through an analysis of the Royal Commission Case Study No 6: The responses of a primary school and the Toowoomba Catholic Education Office to the Conduct of Gerald Byrnes. Through concrete examples, this article analyses the ways in which criminal law organises irresponsibility through the individuation of responsibility and the emphasis upon subjective culpability. These practices ensure irresponsibility for actors for systemic failures.
\end{abstract}

\section{INTRODUCTION}

The current Royal Commission into Institutional Responses to Child Sexual Abuse has demonstrated serious long-term failures to prevent and adequately respond to child sexual abuse by institutions. These failures have occurred not only in the past, but continue to occur in the present, in a broad variety of institutions that have contact with children including government agencies, churches, private companies, and community organisations delivering out-of-home care, childcare, education, sporting, recreational and cultural activities for children. The Royal Commission is focused upon systemic failure by institutions 'caring' for children and responses by the legal system. It is the latest in a series of governmental and non-governmental inquiries into abuse of children in institutions. ${ }^{1}$ The terms of reference require the Royal Commission to identify and focus the inquiry and recommendations upon systemic issues:

At the end of our inquiry, our final report must identify best practices and recommend the laws, policies, practices and systems that will effectively ... respond to the sexual abuse of children in institutions. ${ }^{2}$

\footnotetext{
1 Shurlee Swain, History of Australian Inquiries Reviewing Institutions Providing Care for Children (Royal Commission into Institutional Responses to Child Sexual Abuse, 2014).

2 Commonwealth, Royal Commission into Institutional Responses to Child Sexual Abuse, Interim Report: Volume 1 (2014) 1.
} 
Institutions have a responsibility to appropriately respond to child sex abuse, but many have failed to respond to reports, or if they have, have not done so effectively. Although there is an existing legal framework, the underlying assumption is that laws and regulations have failed in specific ways to protect children in the past, but that this can be remedied. The long-term continued failure by institutions to respond to sexual abuse raises questions such as why does this continue happening? Why can't the law stop these failures? And why are so few, if any, held responsible? It is assumed that a better articulation of legal responsibilities will protect against future systemic failure. On this account, failure to protect can be seen as an aberration or anomalous and can be remedied.

This approach by the Royal Commission accords with the widely understood perception that law provides contemporary society with its most important means of organising responsibility. The law tells us right from wrong, what not to do and what to do, our duties and our responsibilities - backed by sanctions if we breach these rules. Through a combination of coercion and claim to correctness, ${ }^{3}$ legal regulation plays a crucial role in defining and limiting responsibility across a broad range of areas of social life. On this understanding, a failure to hold actors responsible for systemic failure is aberrant and can be remedied. This article adopts a contrary view. Rather than regarding the law as a system of responsibility, I argue that it can be read instead as organising irresponsibility. I draw upon Scott Veitch's ideas in Law and Irresponsibility. ${ }^{4}$ His key argument is that legal institutions operate as much to deflect responsibility for harms suffered as to acknowledge them.

This article focuses on the ways in which the criminal justice system is complicit in organising irresponsibility for systemic failures through an analysis of the Royal Commission Case Study No 6: The Responses of a Primary School and the Toowoomba Catholic Education Office to the Conduct of Gerald Byrnes. ${ }^{5}$ At the time of writing, the Royal Commission has undertaken public hearings in 38 case studies across a range of times, places and institutions. I selected this case study for close analysis in part because it is concerned with relatively recent events, thus dispelling the comforting notion that systemic failures existed only in the past. The case study is also sadly illustrative of themes of systemic failure identified in a broad range of case studies undertaken by the Royal Commission. Gerald Byrnes was a teacher at a non-State school, administered by the Catholic Education Office, Diocese of Toowoomba (TCEO). He touched and fondled girls aged between 10-13 years old on the outside and underneath their clothes. Most of offences were committed during class-time. The first allegation of abuse was made to staff in 2007. From that time on,

3 Robert Alexy, 'The Nature of Legal Philosophy' (2004) 17(2) Ratio Juris 156.

4 Scott Veitch, Law and Irresponsibility: On the Legitimation of Human Suffering (Routledge, 2007).

5 Commonwealth, Royal Commission into Institutional Responses to Child Sexual Abuse, Report of Case Study No 6: The Responses of a Primary School and the Toowoomba Catholic Education Office to the Conduct of Gerald Byrnes (2015). 
staff and management became aware of various aspects of Byrnes offending, and yet no one responded appropriately for more than a year during which Byrnes continued to offend. Byrnes was sent a disciplinary letter in September 2007 relating to some of the allegations. In June 2008 he retired after another allegation of abuse, but was then re-employed as a relief teacher in July 2008 until his arrest in November 2008.

The focus of this article is not upon Byrnes, but the officials around him who could (and should) have done something to prevent and/or react to the abuse, but did not. I am using the term 'official' to include staff, management and the organisation TCEO. This article analyses some of the key ways in which criminal law consistently organises the irresponsibility of officials by separating the link between actor and consequences. A key concern of this article is that organisations are most likely to cause systemic harms, and yet the more complex an organisation, the less likely it is to be held criminally responsible.

Part II provides a justification for approaching systemic failure from the perspective of irresponsibility practices, and articulates a concept of ir/responsibility. Part III analyses the ways in which criminal law organises irresponsibility through the individuation of responsibility and the emphasis upon subjective culpability. These practices ensure irresponsibility for actors for systemic failures. Part IV considers an example of how responsibility practices might be reshaped and redefined in order to effectively attribute blameworthiness in cases of systemic failure.

\section{Historical Inquiries and Ir/Responsibility Practices}

Systemic failures to protect against, and respond adequately to, child sexual abuse in institutions have recurred across time and place. ${ }^{6}$ Veitch's idea of law as irresponsibility provides an alternative perspective with which to view the failure of law to hold actors accountable for systemic failures and possibly to come up with alternative ideas for reform. There is a wealth of excellent literature available about the difficulties the criminal justice system has had grappling with corporate responsibility. ${ }^{7}$ Rather than the usual approach of conceiving of this as a failure of the criminal law to ascribe responsibility, Veitch's approach suggests regarding this as a success in organising irresponsibility. Observing the ways in which law assists in the proliferation of irresponsibility within and of organisations

$6 \quad$ For example, see Kathleen Daly, 'Conceptualising Responses to Institutional Abuse of Children' (2014) 26(1) Current Issues in Criminal Justice 5.

7 For example, see Brent Fisse and John Braithwaite, 'The Allocation of Responsibility for Corporate Crime' (1988) 11 Sydney Law Review 469; Brent Fisse and John Braithwaite, Corporations, Crime and Accountability (Cambridge University Press, 1993); Jonathon Clough and Carmel Mulhern, The Prosecution of Corporations (Oxford University Press, 2002); Celia Wells, Corporations and Criminal Responsibility (Oxford University Press, 2002); Angelo Capuano, 'Catching the Leprechaun; Company Liability and the Case for a Benefit Test in Organic Literature' (2009) 24 Australian Journal of Corporate Law 177. 
may help to re-imagine and re-arrange institutional responses to sexual abuse in practical ways.

In her analysis of past Australian inquiries into institutions providing care for children, Swain identifies themes of irresponsibility that continue to resonate today. ${ }^{8}$ Swain identifies an historic tendency to ignore (sexual) abuse, and where it could not be ignored, a willingness to individualise the problem - whether by blaming the victim or the acts of individual 'perverts' or 'sex fiends'. In addition, Swain notes that there was a lack of almost any criminal legal response to abuse within institutions until the 1990s. For example, before the 1990s although many children died in 'care' in Australia, Swain asserts that there were only three instances in which coronial inquiry led to criminal charges being laid. Only one of these deaths led to imprisonment, in the other two it was asserted that 'although the behaviour that led to the deaths was lamentable, it was understandable given the difficulties posed by the types of children who were being "cared" for' ${ }^{9}$ The most recent inquiries, from the late 20 th century onwards have moved away from depending solely on the evidence of 'experts' and have drawn upon survivor testimony. ${ }^{10}$ Survivor testimony has disrupted the notion that sexual abuse was an individual problem, and shown that the problem was endemic to institutional settings. ${ }^{11}$

Although the Royal Commission provides a clear and consistent narrative that sexual abuse is not an individual problem, I argue that the structures of the criminal justice system continue to respond (or not) to systemic failures within a framework of individualised (ir)responsibility. Swain notes that the response to survivor testimony is often an apology in recognition of past harms suffered. She draws upon Torpey's theory that the phenomenon of apology arises out of a 'declining trust in alternative visions of society'. Rather than organise to change, we now 'organise to mourn' with the result that history and memory have now become 'central

$8 \quad$ Swain, above $\mathrm{n} 1$.

9 Ibid, 8.

10 Swain asserts that the practice changed with the Human Rights and Equal Opportunity Commission, Bringing Them Home: Report of the National Inquiry into the Separation of Aboriginal and Torres Strait Islander Children from their Families (1997) 162. Although sexual abuse was not specified in the terms of reference it was singled out for special treatment in the subsequent reports. Australian Senate Community Affairs References Committee, Lost Innocents: Righting the Record Report on Child Migration (Senate Printing Unit, 2001) 75; Senate Community Affairs References Committee Forgotten Australians: A Report on Australians Who Experienced Institutional or Out-of-Home Care as Children (Senate Printing Unit, 2004) 103; Leneene Forde, Report of the Commission of Inquiry into Abuse of Children in Queensland Institutions (The Inquiry, 1999) iv, 87. The current Royal Commission also relies upon victim testimony, and has released an interim report with hundreds of pages devoted to summarising survivor testimony, Commonwealth Royal Commission into Institutional Responses to Child Sexual Abuse, Interim Report Volume 2 (2014).

11 Swain, above n 1, 11. 
to the political project'. ${ }^{12}$ Theorists regard the 21 st century as a culture of regret in which governments have turned from focusing on future policy to address the errors of the past. ${ }^{13}$ Veitch has also noted a recent habit by politicians of empty apologies, accepting full responsibility as a way of denying responsibility. ${ }^{14}$ The Royal Commission inquiries have led to reluctant and tardy apologies by (some) officials, but these apologies are empty if not accompanied by a responsibility for change. Whilst it may be argued that institutions should wait until final overall findings from the Royal Commission, the Royal Commission has been making findings and recommendations specific to institutions as the public hearings continue. These provide institutions with clear guidance of specifics as to how they can improve prevention of, and responses to, child sexual abuse. These institutions can and should be judged by the extent to which they meet these specific guidelines. ${ }^{15}$

Law is regarded as a key institution for organising responsibility. Theorists have noted the etymology of responsibility of response or answerability. Thus Norrie argues "responsibility” involves being "called to respond" (answerability) and being "found responsible" (culpability)'. ${ }^{16}$ Criminal law involves an actor facing a demand for a response, and if sufficiently blameworthy, that response may be met with criminal sanctions. There are a variety of types of responsibilities, for example, Hart outlines a taxonomy of responsibility. ${ }^{17}$ In addition, each of these responsibilities are subject to interpretation, giving way to contestation as soon as it comes

12 Swain, above n 1, quoting John Torpey, 'Introduction: Politics and the Past' in John Torpey (ed), Politics and the Past: On Repairing Historical Injustices (Rowman and Littlefield, 2003) 1.

13 Jeffrey Olick, The Politics of Regret: On Collective Memory and Historical Responsibility (Routledge, 2007).

14 Scott Veitch, 'Book Symposium: Author's Responses to the Commentators' (2009) 34 Australian Journal of Legal Philosophy 248, 248, Veitch quotes Tony Blair's response to the inquiry into intelligence leading to the invasion of Iraq showing that there were no weapons of mass destruction: 'For any mistakes made, as the report finds, in good faith I of course take full responsibility'.

15 For example, Scouts Australia was recently the subject of public criticism for a five-day delay in reporting an allegation of indecent assault to police. Scouts Australia asserted that this was due to a failure to 'lack of understanding of Scout protocol and procedures by some leaders', 'Scout Leader Charged Over Alleged Indecent Assault of 14yo Girl, Delay in Incident Report', Australian Broadcasting Corporation (online), 10 January $2016<$ www.abc.net.au/news/2016-01-10/scoutleader-charged-over-alleged-indecent-assault-of-14yo-girl/7079026>. Scouts Australia had been a subject of the first case study undertaken by the Royal Commission in 2013, published in early 2014, in which the protocol and procedures by Scouts were criticised. Scouts had had more than two years to adjust protocol and procedures and train leaders, so claims of lack of 'understanding' are not persuasive. Commonwealth, Royal Commission into Institutional Responses to Child Sexual Abuse, Report of Case Study No 1: The Response of Institutions to the Conduct of Steven Larkins (2014).

16 Alan Norrie, 'Simulcra of Morality? - Beyond the Ideal/Actual Antimonies of Criminal Justice' in Anthony Duff (ed), Philosophy and the Criminal Law (Cambridge University Press, 1998) 101, 114.

17 HLA Hart, Punishment and Responsibility (Clarendon Press, 1968). 
to articulating substantive content. Because of the varieties of responsibility and the interpretation of each one, Veitch argues that responsibility should not be seen as a timeless, pure concept, but a cluster of notions, and thus best regarded as Cane has termed 'responsibility practices'. ${ }^{18}$ These practices are a matter of construction and ascription, ${ }^{19}$ and provide ways of dealing with and legitimating regulatory problems and solutions occurring across modern society. The absence of a single definition of responsibility and debates about the interpretation of specific responsibility practices highlights that responsibility is socially and historically contingent, and thus subject to definition and redefinition. Veitch argues that:

['R]esponsibility practices' inadvertently bring with them practices of irresponsibility, the essence of which lies not in the breach of norms, but in the simultaneous removal of responsibility according to potentially complex, but nonetheless patterned, processes of disconnection, disaggregation and disavowal. ${ }^{20}$

As I argue below, Veitch argues that the division of labour is key in irresponsibility practices. This division of labour is replicated in the framing of responsibility. Responsibility practices can be framed in many ways - not just by legal discourse - but others such as moral, political and economic. Thus we might speak of a person having a moral responsibility to report sexual abuse, but not necessarily having a legal responsibility. ${ }^{21}$ Although there are different frames, Veitch argues that law's articulation of responsibility and irresponsibility practices is particularly significant because legal normativity brings with it a socially effective institutionalised force and the claim that this force is right or just (the claim to correctness):

It is because of the former (socially efficacious coercion) that the latter (correctness) necessarily extends its reach beyond matters of mere internal legal validity and makes its claim to legitimacy effective in the terrain of social relations more generally. And it is this that constitutes the third feature of law in contemporary society: that is, given law's claim to correctness and its ability to enforce it, law attains a level of priority and prominence in social life and its normative hierarchies even when its effects may, in fact, be claimed to be unjust. ${ }^{22}$

Accordingly, law's measure increasingly dominates social life, including morality and politics. If an actor has fulfilled their role responsibly according to law, then a moral question of responsibility may not even be raised at all. Veitch thus accords great power to law in its articulation and organisation of responsibility and irresponsibility. Underlying his scathing critique of law is thus the possibility of hope that law can

18 Peter Cane, Responsibility in Law and Morality (Hart, 2002).

19 Nicola Lacey, 'Responsibility and Modernity in Criminal Law' (2001) 9 Journal of Political Philosophy 249.

20 Veitch, above n 4, 28.

21 This is in accordance with the positivist notion separating legal and moral questions, see HLA Hart, 'Positivism and the Separation of Law and Morals' (1958) 71 Harvard Law Review 593.

22 Veitch, above $\mathrm{n} 4,26$. To construct this argument Veitch draws upon Alexy, above n 3 . 
use this power to accomplish change from irresponsibility practices to responsibility.

The replication of the division of labour also occurs within the legal system. We divide up legal matters into various registers. The Royal Commission is considering institutional responses in a variety of different legal registers including the civil sphere. ${ }^{23}$ Unlike many other examples in the Royal Commission, compensation has been paid in response to Byrnes' offending. More than $\$ 2.25$ million has been paid in damages, costs and administration fees to nine victims and some family members in relation to Byrnes' offences. ${ }^{24}$ In the criminal register, the actual offender Gerard Vincent Byrnes was sentenced to 10 years' imprisonment, including a non-parole period of eight years, after he pleaded guilty to 44 child sexual abuse offences against 13 girls who were then aged between eight and 10 years. Ten of the offences were particularly serious and involved digital vaginal and anal rape. The division of labour in different legal registers means that the responsibility of each area of law is restricted. Thus the criminal justice system has a limited role in responding primarily to the perpetrators and those who have failed to fulfil mandatory reporting duties. Other issues are left to other areas of law, or not considered at all.

Veitch is focused not upon law-breaking, but on situations where obedience to the law is complicit in the commission of suffering.

Our key concern here is not with that which is illegal or criminal, but with that which is legal. It is with exposing and coming to terms with the fact that the cultural, conceptual, institutional crucible of legal organisation is able to carry out an alchemy that can turn mass tragedy into legitimate action, genocidal annihilation into the prerogative of sovereign right. ${ }^{25}$

His examples include the application of sanctions in Iraq, apartheid in South Africa and the Truth and Reconciliation Commission, forms of colonialism, and environmental or nuclear devastation. In all these examples, there is international recognition of harmful consequences, and yet almost no official or organisation is held responsible for causing these harms. Veitch's idea of irresponsibility is different from negligence. The concept of negligence applies in criminal law where a person has culpably failed to meet an objective standard. Where this is due to an omission, the prosecution must also establish a legal duty to act. ${ }^{26}$ Veitch's argument precedes the questions of negligence - where no duty can be established at law, and where law might even exclude any question of duty or responsibility for harms to arise at all. Thus, even where harm is recognised, the question of responsibility does not arise at law. I will draw upon Veitch's arguments to

23 The vexed issue of civil compensation would also benefit from an analysis from the perspective of irresponsibility practices, as there seem to be so many (legal) impediments to paying compensation. See Royal Commission into Institutional Responses to Child Sexual Abuse, Redress (14 September 2015) <www.childabuseroyalcommission.gov.au/policy-and-research/redress $>$.

24 Commonwealth, Royal Commission into Institutional Responses to Child Sexual Abuse, above n 5, 45.

25 Veitch, above n 4, 12.

26 Nydam v The Queen [1977] VR 430. 
explore through the detail of the case study the ways in which criminal law is complicit in the evasion of responsibility by officials for their decisions and consequences, or worse, the creation of a zone of non-responsibility where questions of responsibility vanish entirely. ${ }^{27}$

\section{Criminal LaW AND IrResponsibility}

A key insight from Veitch is that legal concepts and categories should be analysed to show how they allow irresponsibility to be normalised. Veitch argues that law's account of ir/responsibility is important because it has a crucial role in allowing harms to proliferate and in legitimating these through making responsibility for these harms disappear. ${ }^{28}$ This is particularly the case in relation to systemic harms caused by complex organisations. At a time when we emphasise our independence and individuality, this is accompanied by increasing reliance to an almost complete dependence on others for basic human needs and activities. In particular, we are more and more dependent on complex organisations. Systemic harms are most likely to be inflicted by complex organisations, and yet the criminal law's account of responsibility within and of institutions is particularly weak. We need to re-examine the ways in which central concepts of criminal law organise ir/responsibility within and of complex organisations.

A key effect of irresponsibility practices is to splinter any link between the actor and consequences. I explore two key, interrelated ways in which criminal law organises the irresponsibility of officials first, the division of labour and the individualisation of responsibility; and secondly, the focus on the state of mind of the accused in ascriptions of responsibility.

\section{A Duty of Care}

Veitch analyses the division of labour and processes and practices of individualisation as integral to irresponsibility practices. These practices are particularly resonant in complex organisations, which are highly dependent upon the division of labour. Employees are allocated particular roles and tasks. Responsibilities are defined by reference to the task or job itself, rather than other potential sources of responsibility, such as the individual responsibility of the person occupying a role. A person is judged by the extent to which they have fulfilled the terms of the job, not the effects of their actions. Actions that fulfil job responsibilities are blameless, regardless of their outcomes - 'I was just doing my job'. Responsibility for a role is accompanied by a zone of non-responsibility beyond that defined role. Veitch argues, 'it segregates responsibility for role from responsibility for consequences; it legitimates the separation of intention from ultimate outcomes and does indeed, offer the presumption of these persons' actions 
as both responsible and blameless'. ${ }^{29}$ It is only rarely that the claim 'I was just doing my job' is found to be deeply problematic. In the normal run of things, these claims carry the weight of justification that sees the question of responsibility successfully measured by the role.

The division of labour and practice of role responsibility individualises responsibility. Veitch argues that in modern society responsibility is focally conceived of as individual responsibility, ${ }^{30}$ based on the enlightenment ideal of the autonomous individual which is itself part of a long historical process. ${ }^{31}$ In contemporary society there is a discrepancy between the idea of the autonomous individual and the social reality of dominant bureaucratic organisations. In these complex organisations, individuals have little or no defining capacity in their roles and their actions are severed from responsibility for the consequences. Veitch draws upon Stanley Milgram to augment his arguments about the division of labour and irresponsibility practices. In his analysis of obedience and the production of harm, Milgram exposed the significance of compartmentalisation, authority and expertise. Individuals acting in a role over which they have little or no defining capacity, feel a lack of responsibility not only to far-off consequences, but even to their own actions. Under such conditions, the actor, "no longer sees himself as the efficient cause of his own actions, this having been subsumed under and attributed to the role itself'. ${ }^{32}$ The division of labour and authority means that:

There is a fragmentation of the total human act; no one man decides to carry out the evil act and is confronted with its consequences. The person who assumes full responsibility for the act has evaporated. ${ }^{33}$

Criminal law reflects and reinforces the division of labour in how it constructs duties. Most cases of systemic failure involve omission - the failure by officials to act. The criminal law is famously reluctant to hold actors responsible for omissions. ${ }^{34} \mathrm{~A}$ legal duty, rather than a moral duty must be established, before someone can be held responsible for an omission. The statement of this principle is often accompanied by the graphic example of allowing a baby to crawl to its death in a puddle of water, provided one is not related to it and does not encourage it. The reiteration of the division of labour is apparent here - even though it may be morally reprehensible, the law has no responsibility in the absence of a legal duty. The case study provides ample examples of the division of labour and

29 Ibid, 48.

30 Ibid.

31 Lacey, above n 19.

32 Veitch, above n 4, quoting Stanley Milgram, Obedience to Authority (Harper and Row, 1974) xii.

33 Ibid, 11.

34 Andrew Ashworth, Positive Obligations in Criminal Law (Hart, 2013); Andrew Ashworth and Eva Steiner, 'Criminal Omissions and Public Duties: The French Experience' (1990) 10 Legal Studies 153; George Fletcher, Rethinking Criminal Law (Little Brown, 1978); AP Simester, 'Why Omissions are Special' (1995) 1 Legal Theory 311; Glanville Williams, 'Criminal Omissions - The Conventional View’ (1991) 107 Law Quarterly Review 86. 
processes of individualisation in irresponsibility practices. ${ }^{35} \mathrm{I}$ will analyse examples going up the chain of command.

\section{The Student Protection Contact: Long}

In 2007, Byrnes was one of two staff members at the school who had been appointed as student protection contacts by the principal, Terence Hayes. Student protection contacts had responsibility for assisting the principal to ensure that suspicions or disclosures of harm, including sexual abuse, were reported to police in accordance with the school's applicable policies and procedures for student protection (set out in the school's Student Protection and Risk Management Kit). On 3 September 2007, KQ, the father of a student in Byrnes' Year 4 class, telephoned Hayes and said that his daughter, KH, had said that Byrnes had put his hand inside her school shirt and that he had touched her and made her feel uncomfortable. KQ and Hayes arranged to meet at the school to discuss the matter. According to Hayes, by the time his telephone conversation had finished, he had formed the opinion that he was dealing with serious allegations of sexual abuse against a child. ${ }^{36}$

Ms Long, the Learning Support Teacher and other student protection contact, was present at the meeting where $\mathrm{KH}$ reported Byrnes' actions. Long asserted that she understood her role at the meeting with $\mathrm{KQ}$ and $\mathrm{KH}$ to be that of 'note-taker'. She believed it was Hayes's responsibility to ensure that the allegations were properly documented as he 'was in charge, not me'. Long stated:

[I]t was the principal who filled out those forms with the knowledge you gave them, or that we filled out the forms with the principal there with us. It was never something that we should have done on our own, filled out those forms on our own and did it by ourselves. ${ }^{37}$

Long abdicated responsibility in the hierarchy to her boss, but also to the parent. ${ }^{38}$ It was not her job to report to the police, and the law imposed no duty on her to report to the police, the duty was imposed on Hayes. The Royal Commission noted that while the student protection kit did not impose an obligation on Long to make a report to the police, she accepted that there was nothing to have stopped her from doing so and that child

35 The Royal Commission generally has demonstrated many claims of irresponsibility on the argument 'it was not my job'. A notable exception in the face of great institutional opposition was by Bishop Wilson in response to John Nestor. Commonwealth, Royal Commission into Institutional Responses to Child Sexual Abuse, Report of Case Study No 14: The Response of the Catholic Diocese of Wollongong to Allegations of Child Sexual Abuse, and Related Criminal Proceedings, Against John Gerard Nestor, a Priest of the Diocese (2014).

36 Commonwealth, Royal Commission into Institutional Responses to Child Sexual Abuse, above n 5 .

37 Ibid, 18.

38 The parent also acted according to a division of labour. He 'thought that the school would look after things' and that the allegation of abuse would be investigated internally: ibid, 17. 
protection is everyone's responsibility. She stated that she did not report because she believed Hayes was dealing with the allegations, even though she was aware that Hayes did not report the allegations to police. ${ }^{39}$

On 4 September, another disclosure of abuse was made to the acting principal Wagstaff by another parent, whose daughter had overheard KA telling KH that Byrnes had put his hand down her skirt. Wagstaff then informed Long. Despite being aware of the other allegations, Long counselled Wagstaff against speaking with KA directly because the information was 'third hand'. Long also suggested to Wagstaff that she inform the mother that she could not speak with KA directly, and that Wagstaff should speak with both Fry and Hayes. Wagstaff then informed Fry who told her to put it in writing for Hayes.

As a consequence of these additional allegations, Long's opinion in relation to the allegations against Byrnes changed. By this time, Long was of the opinion that 'clearly [Byrnes] had to be investigated, so something inappropriate - something was not right'. ${ }^{40}$ Despite her change of mind, Long did not document her concerns or take any other action 'because I wasn't the first person to receive that complaint'. ${ }^{41}$ Long's assertion of irresponsibility was reflected at law. She had no legal duty to report and was thus not responsible at law. Although her failure to report meant that Byrnes was able to continue to offend, the link between her failure and the harmful consequences is severed.

\section{The School Principal: Hayes}

Like Long, the school principal Hayes also did not report the allegations of abuse to police, instead he turned to the TCEO. Hayes accepted that, as principal, he had an obligation under the student protection kit to document any allegations of child sexual abuse he received and report these to the police. He accepted that he did not comply with this obligation, but explained that he did not comply with the kit because he had been advised that TCEO 'is our first port of call'. ${ }^{42}$ Although the TCEO rejected this contention it was supported by another former principal that he had 'a clear recollection of being told on more than one occasion by Catholic Education representatives, directions to the effect that: the mandatory reporting law is in place, we have dealt with the mandatory reporting law in the manual, but any report is to be directly given or communicated to your next in line'. ${ }^{43}$ Hayes' justification is consistent with Veitch's arguments about the division of responsibility and Milgram's analysis of obedience:

When invited by the Royal Commission to explain why he did not report to police the allegations received from $\mathrm{KH}$ during the meeting on 6 September

39 Ibid, 19.

40 Ibid, 28.

41 Ibid.

42 Ibid, 19

43 Ibid, 20. 
2007, Hayes stated that he 'saw [himself] as part of a system' and that he 'should have been more assertive in [his] judgments'. ${ }^{44}$

Even when discussing his shortcomings in hindsight, his focus was upon his failure to follow procedures, rather than the consequences of his actions.

It's an oversight that I find very hard to come to terms with, and given the implications of that, it brings a lot of hurt to me and my family, and life has changed because anyone who knows me knows that I am a pedantic person and - I just - I can't reason with it ... ${ }^{45}$

3

\section{The TCEO}

Hayes orally reported the first allegation to TCEO to Fry (designated Senior Education Officer) who then reported to Hunter (Senior Education Officer). There was some dispute in evidence about how much Fry was told by Hayes. Hayes sent Fry a draft letter which detailed additional allegations, but downplayed the original allegation. Fry did not follow-up on any discrepancies between the original oral report and draft letter. He asserted it was not his job to investigate, nor to follow-up on 'gossip'. Fry showed the draft letter to Hunter. The Royal Commission details difficulties in communication between Hayes and the TCEO, and within the TCEO, but notes that there was sufficient information in the draft letter to justify contacting the police. Hunter denied that it was his responsibility to contact the police.

The Report shows a shifting of responsibility up and down the hierarchy throughout the organisation with the outcome that no-one claimed, or was held, responsible by the criminal legal system for the failure to report Byrnes. ${ }^{46}$ This reflects Veitch's arguments regarding the disaggregation of roles setting up a complex apartheid of responsibilities that furthers and legitimates the possibilities of disavowal of responsibility. ${ }^{47}$ The concern here is that harm and suffering to the children came about not because people were not doing their jobs, but rather that they were. Organisations are most likely to cause systemic harms, and yet the more complex the organisation, the less likely that anyone (or thing) will be held responsible. The further up the chain of command the less likely is responsibility to be attached due to diversionary practices and structural dispersions. As shown in the case study, there may be a lack of causal connection and temporal and spatial dispersions. For example, Hunter and Fry were not present at the school and were only hearing indirectly about allegations of abuse. Veitch argues that this produces an asymmetry of the production of suffering and responsibility for it. The greater the suffering, the less likely

$44 \quad$ Ibid, 21.

45 Ibid, 34.

46 Hayes, Fry and Hunter were held responsible in a different sphere. They lost their jobs in December 2009 for the failure to respond appropriately to the abuse allegations. Ibid, 8.

Veitch, above $\mathrm{n} 4,50$. 
responsibility can be established for it. Only Hayes was charged with the failure to report. He was tried on a single charge of failing to comply with a mandatory reporting obligation under s 366(4) of the Education (General Provisions) Act 2006 (Qld). Hayes successfully defended the charge on the basis that he had reported to the TCEO in accordance with s 366(2) of the Act and that the obligation to report the information to police lay with a person in the school's governing body, not himself. ${ }^{48}$ In November 2011 , this section was amended to require a principal to report even if they had reported to the school's governing body. This reform would only cover Hayes' omission to report, but no-one else would be responsible at criminal law for their failures.

The reports by the Royal Commission make for distressing and depressing reading. There is an overwhelming sense of failure and lost opportunities. In Byrnes' case, only one person would have needed to have reported the allegations to the police. ${ }^{49}$ When an allegation was finally reported by a mother of a victim to the police in November 2008, the police response was immediate and effective. Despite this, officials at the school and the TCEO averred that they were not responsible, and these disavowals of responsibility were reflected and reinforced at law.

\section{B Subjective Culpability}

The effects of the division of labour are exacerbated by modern notions of responsibility. Veitch argues that modern responsibility practices distinguish between mind and deed, intention and consequences. Autonomy or free will is the central understanding of responsibility. The central idea is that a person cannot, and should not, be held responsible unless they intentionally or knowingly did the wrong thing. Philosophers of wickedness have labelled this a positive model of wickedness and noted the way in which it dominates the normative imagination..$^{50}$ Intention and/ or knowledge are not the exclusive measures of responsibility, but they are dominant. It is frequently represented in popular fiction. ${ }^{51}$ This means that it is hard to imagine holding an actor responsible for outcomes that they did not foresee or intend.

The dominance of the requirement of wrongful intent or knowledge is reflected and reinforced in criminal legal doctrine in the dominance of

48 Commonwealth, Royal Commission into Institutional Responses to Child Sexual Abuse, above n 5, 7 .

49 This point leaves aside issues of police failures to adequately respond to allegations of sexual abuse.

50 For example, Mary Midgley, Wickedness: A Philosophical Essay (Routledge, 1984, 2001 ed); Susan Neiman, Evil in Modern Thought (Princeton University Press, 2002).

51 Positive models of wickedness are the norm in popular fiction and include Satan, Iago, Dr Hannibal and villains in all the James Bond movies and comic book films. In contrast, it is very rare to come across a representation of evil as negative. An exception is the beautiful representation of evil in The Farthest Shore: Ursula Le Guin, The Earthsea Quartet (Penguin, 1968). 
subjective culpability in attributions of blameworthiness. ${ }^{52}$ The separation of mind and body is reflected in the conceptual division of offence components into mens rea (guilty mind) and actus reus (wrongful act and consequences). Subjectivism is ostensibly articulated in the Latin maxim that is often cited as fundamental to the criminal law: actus non facit reum nisi mens sit rea - stated by Blackstone 'as a vicious will without a vicious act is no civil crime, so on the other hand, an unwarrantable act without a vicious will is no crime at all'. ${ }^{53}$ That is, according to general principles of the criminal law, mens rea or subjective blameworthiness is central to determinations and attributions of culpability. ${ }^{54}$ Subjectivism has been asserted as a general principle of criminal law doctrine by the High Court in He Kaw Teh:

There is a presumption that mens rea, an evil intention, or knowledge of the wrongfulness of the act, is an essential ingredient in every offence ... unless displaced by statute or subject matter..$^{55}$

This presumption can only be overturned through precedent or express statutory reform. The emphasis by the High Court on the presumption of mens rea reflects and reinforces the dominance of the pattern of subjective criminality in determinations of blameworthiness in the criminal justice system. ${ }^{56}$ The High Court expressed concern for 'luckless victims', who through no fault of their own are held criminally liable, and the harshness of holding an accused liable in the absence of any 'fault' on his part. ${ }^{57}$ That is, the case expresses the subjectivist ideal that an accused should not be held liable for outcomes that were unintended or accidental. ${ }^{58}$

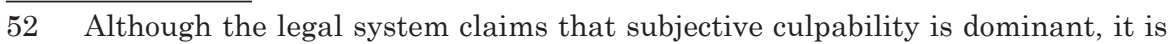
recognised that the exceptions to the rule far outnumber the rule itself. See Alan Norrie, Crime, Reason and History: A Critical Introduction to Criminal Law (Cambridge University Press, 2014).

53 William Blackstone, Commentaries on the Laws of England: Book the Fourth: Of Public Wrongs (Clarendon Press, 1769) 21.

54 This interpretation of the general principle depends on a specific definition of mens rea as 'guilty mind'. As Fletcher has noted the ambiguity of the term mens rea is framed by whether or not it is used in a descriptive or normative sense: Fletcher, above n 34, 398.

55 (1985) 15 A Crim R 203 approving the statement in Sherras v De Rutzen [1895] 1 QB 918, 921.

56 See also MacPherson v Brown (1975) 12 SASR 184, 189 (Bray CJ): 'It is contrary to fundamental principles and the whole tenor of modern thought to judge a man in a criminal court, except under statutory compulsion, not by his actual intention, knowledge or foresight, but by what a reasonable and prudent man would have intended, known or foreseen in the circumstances'.

57 Lin Chin Aik v The Queen [1963] AC 160,174 (Judicial Committee of the Privy Council). See also L Waller and CR Williams, Criminal Law: Text and Cases (Lexis Nexis, 9th ed, 2001).

58 Andrew Ashworth, 'Taking the Consequence' in Stephen Shute, John Gardner and Jeremy Horder (eds), Action and Value in Criminal Law (Clarendon Press, 1993) 123, 124: 'If a subjectivist were drafting a new criminal code, all these cases would be made to depend on the defendant's culpability rather than the outcome in a particular case. The effect of this on the form of the criminal law would be 
The emphasis upon subjective culpability is apparent in how the criminal justice system responds (or not) to officials. The primary means for holding officials responsible for failures to respond to child sexual abuse is through mandatory reporting offences. Mandatory reporting offences are framed in terms that are consistent with subjective culpability. For example, the Crimes Amendment (Protection of Children) Act 2014 (Vic) introduced new offences of 'failure by a person in authority to protect child from sexual offence' and 'failure to disclose sexual offence against child under the age of 16 years'. Section $49 \mathrm{C}$ requires that a person in a position of power or responsibility who '(2)(b) knows that there is a substantial risk that the person will commit a sexual offence against a relevant child - must not negligently fail to reduce or remove that risk'. Section 327(2) requires that a person who has information to 'form a reasonable belief that a sexual offence has been committed' must report that information to the police. Both these offences require some subjective culpability on the part of the accused in the form of 'reasonable belief' or 'knowledge'.

The problem is that in complex organisations knowledge is diffused, difficult to establish or prove, because of the organisation itself. The emphasis upon, and requirement of, wrongful knowledge or intention is an irresponsibility practice because the nature of organisations means that subjective culpability is almost never able to be established. This can be shown in various ways in the case study. The case study shows a lack of knowledge by staff of the mandatory reporting rules. Hayes claimed that he had never made a mandatory report of child sexual abuse, and even though his duties were articulated in the student protection kit, he had never actually read it. He thus deferred his responsibility to understand the nature of his responsibility to the TCEO, who he then claimed had advised him his duty was to report to them, rather than the police. Wagstaff also asserted that she had never read the child protection kit from cover to cover. When told by a parent of an allegation of abuse, Wagstaff formed no opinion of whether it was abuse, but just recorded it. She was not aware of provisions in the kit that if there is doubt about an allegation, the decision about how to assess the information must be made in favour of acting on the allegation. ${ }^{59}$

There was also an absence of understanding by staff of grooming behaviours. When informed of an allegation against Byrnes, Long stated:

Well Gerry needs to stop giving out lollies to children particularly the Year 7 girls before and after school and having girls hanging off him in the playground when he is on yard duty. He has even put a chocolate bar in the desk of a Year 7 girl.

It was due to the nature of the organisation that Long was able to assert that she did not know that this was classic grooming behaviour as she had not been trained to recognise it. Another teacher had also seen Byrnes

quite radical, since many offences are currently defined by reference to the result'. See also Fletcher, above n 34, 138.

59 Commonwealth, Royal Commission into Institutional Responses to Child Sexual Abuse, above n 5, 27. 
seat a girl on his knee, but had similarly not connected this with grooming behaviour, or at least had not reported it.

Many of the case studies in the Royal Commission highlight a tendency by management to blame staff for failures to know and understand mandatory reporting rules and recognise grooming behaviours, whilst staff claim that they have not been adequately trained. ${ }^{60}$ What is clear from the reports is that this ignorance is sufficiently widespread to suggest that it is systemic rather than limited to the problems of particular individuals. The case study demonstrated TCEO's failure to train, apply and enforce policies. The failure by management to train, apply and enforce policies meant that staff were ignorant and unable to prevent Byrnes from offending or respond appropriately to his offending. It is not the junior staff members who should be held criminally culpable, because their ignorance and failure to act was due to failures by management. Given that the principal did not know the rules and procedures, or if he did, did not obey them, there was little chance that staff below him would have known or acted upon the rules. Management should have trained, applied and enforced existing policies. Decades of research around mandatory reporting confirm the need for training staff to recognise child abuse. ${ }^{61}$ There is a plethora of research existing that has demonstrated that effective reporting by teachers is influenced by their awareness of the duty to report, ${ }^{62}$ knowledge of the content of that duty, ${ }^{63}$ and their attitude towards that duty. ${ }^{64}$ Despite this, numerous studies have found that professionals who are required to report child abuse and neglect indicate that they have not had the training required to equip them to fulfil that role. ${ }^{65}$ This demonstrates that the development of

60 This is powerfully demonstrated in the case study of the YMCA: Commonwealth, Royal Commission into Institutional Responses to Child Sexual Abuse, Report of Case Study No 2: YMCA NSW's Response to the Conduct of Jonathan Lord (2014).

61 Ben Mathews and Kerryann Walsh, 'Mandatory Reporting Laws' in Alan Hayes and Daryl Higgins (eds), Families, Policy and the Law (Australian Institute of Family Studies, 2014) 131.

62 Wesley Crenshaw, Lucinda Crenshaw and James Lichtenberg, "When Educators Confront Child Abuse: An Analysis of the Decision to Report' (1995) 19(9) Child Abuse and Neglect 1095.

63 Maureen Kenny, 'Teachers' Attitudes Toward and Knowledge of Child Maltreatment' (2004) 28(12) Child Abuse and Neglect 1311.

64 A Goebbels et al, 'Teachers' Reporting of Suspected Child Abuse and Neglect' (2008) 23(6) Health Education Research 941; Russell Hawkins and Christie McCallum, 'Mandatory Notification Training for Suspected Child Abuse and Neglect in South Australian Schools' (2001) 25(12) Child Abuse and Neglect 1603-1625.

65 Hawkins and McCallum, above n 64; Kenny, above n 63; Nadine Abrahams, Kathleen Casey and Deborah Daro, 'Teachers' Knowledge, Attitudes and Beliefs About Child Abuse and its Prevention' (1992) 16(2) Child Abuse and Neglect 229; Maureen Kenny, 'Child Abuse Reporting: Teachers' Perceived deterrents' (2001) 25(1) Child Abuse and Neglect 81; Ben Mathews, 'Teacher Education to Meet the Challenges of Child Sexual Abuse' (2011) 36(11) Australian Journal of Teacher Education 13; Anne Reiniger, Esther Robison and Margaret McHugh, 'Mandated Training of Professionals: A Means for Improving Reporting of 
impeccable policies and laws are pointless in the absence of training and enforcement, yet only South Australia legislatively requires training for mandatory reporters. ${ }^{66}$ The lack of knowledge and awareness is a systemic problem, and current structures proliferate irresponsibility for ignorance.

The lack of knowledge extends beyond lack of training to the nature of the organisation itself. For example, allegations about Byrnes were made to different staff members, who due to lack of awareness about other complaints, did not respond to the allegations as serious or credible. The impact of the division of labour in disaggregating responsibility and impacting upon knowledge is particularly demonstrated in the re-employment of Byrnes after his retirement in June 2008. Hayes told Hendricks that Byrnes was finding it 'a bit difficult, he is having complaints from teachers - from parents, and would like to retire', but did not provide any detail about why the parents were not happy and Hendricks requested no further information, ${ }^{67}$ another example of the effects of the division of labour. She stated that she just assumed that Byrnes was not a 'strong teacher'. From 30 July 2008, Byrnes was re-engaged as a relief or supply teacher at the school, following approval by Hendricks. Hayes claimed that he believed Hendricks knew about the disciplinary letter sent in September 2007. Between 30 July and 14 November 2008, Byrnes performed duties as a relief teacher at the school on at least 15 separate days. Three of the 33 counts of indecent treatment for which Byrnes was ultimately convicted took place during this period. ${ }^{68}$ Presumably if Hendricks had been aware of the allegations she would not have approved his employment as a relief teacher.

The combination of the effects of the division of labour and emphasis upon subjective culpability was also demonstrated at the level of the regulator. The school was a 'Non-State school' within the meaning of s 6 of the Education (Accreditation of Non-State Schools) Act 2001 (Qld). To operate lawfully, it was required to be accredited by the Non-State Schools Accreditation Board (the NSSAB). The Act authorised the prescription of accreditation criteria by regulation, including criteria about 'student welfare processes' ${ }^{69}$ The NSSAB focused solely upon written processes, rather than their implementation. As a consequence of this, the Catholic Diocese was of the opinion that not only the student protection kit complied with all relevant legislative requirements, but also that the NSSAB was satisfied that the policies and procedures were being properly implemented. They assumed that the NSSAB had fulfilled the duty of ensuring that the student safety kit was correct: "in the renewal of our

Suspected Child Abuse' (1995) 19(1) Child Abuse and Neglect 63; Kerryann Walsh et al, 'Case, Teacher and School Characteristics Influencing Teachers' Detection and Reporting of Child Physical Abuse and Neglect: Results from an Australian Survey' (2008) 32(10) Child Abuse and Neglect 983.

66 Mathews and Walsh, above n 61, 139.

67 Commonwealth, Royal Commission into Institutional Responses to Child Sexual Abuse, above n 5, 38 .

68 Ibid, 39.

69 Ibid, 47. 
kit, I felt as though, when it was accredited by the NSSAB, that they had provided key - they had scrutinised it with an expert eye'. ${ }^{70}$ The dispersal and disavowal of responsibility to ensure staff knowledge and implementation of child safety thus occurred at the highest levels.

\section{A Redefinition of Practices of Responsibility}

Veitch has argued that the power of irresponsibility practices is not just the disavowal of responsibility, but that responsibility is not raised as an issue at all. Although the Royal Commission attempts to disrupt disavowals of responsibility, the model of individual subjective culpability is so dominant that it is difficult to imagine holding anyone, including the organisation, criminally responsible for systemic failures. The model is highly individualised and requires knowledge that is unlikely to be established at any level, except perhaps at the lowest levels, but this fails to grapple with systemic failures. There are many ways of improving levels of knowledge within an organisation (for example through the appointment of a specific child safety officer - but in the present Case Study the offender was the child safety officer). Veitch's approach encourages us to analyse the ways in which legal concepts are practices of irresponsibility. Rather than trying solely to improve knowledge and awareness within an institution to satisfy requirements of the model of subjective culpability, Veitch's approach suggests dismantling the dominance of the model of subjective culpability in attributions of blameworthiness. We need to enlarge the normative imagination to include other models of culpability that are more capable of grappling with systemic failure. This is consistent with the argument by the moral philosopher, Mary Midgley, who argues that we need to resuscitate a 'classic' account of wickedness.

The first thing which seems needed here is to recover for use the older, recently neglected, idea of evil as negative - not because it contains the whole truth, but because it does hold an essential part of it. ${ }^{71}$

A central contention of Midgley's book Wickedness, with which I agree, is the need to resuscitate the traditional model of wickedness. This does not mean that the subjective model of culpability is not still relevant, but it needs to be supplemented with a negative model of wickedness that could be applicable to systemic failures like those of TCEO.

The negative account expresses the notion of evil as lack, dearth or failure. Thus wickedness can be conceived as an absence of goodness or grace, ${ }^{72}$ a lack of balance. ${ }^{73}$ Augustine expressed evil as 'knots of cunning calumnies' - highlighting the idea that wickedness is not a positive

$70 \quad$ Ibid, 51.

71 Midgley, above n 50.

72 Thomas Aquinas, On Evil (2003 ed, Oxford University Press, 1274). For Aquinas, evil is the absence of a good that ought to be present.

73 Aristotle, The Nicomachean Ethics (J Thomson and Hugh Tredennick trans, Penguin, 2004). 
presence, but a warping and twisting of that which is good. ${ }^{74}$ Midgley utilises the Aristotelian notion of the golden mean - a balance between too much and too little - to develop the negative account of wickedness. For Midgley, according to this Aristotelian account wickedness occurs where there is a lack of balance. ${ }^{75}$ This account provides an alternative to the modern tendency to think of some emotions as inherently bad (such as jealousy, aggression); and others as inherently good (such as love). On this account, it is not the emotion, but the lack of balance that matters. This analysis applies effectively to bureaucrats like Eichmann, who claimed that he just wanted to be good at his job. His behaviour was culpable because there was a lack of balance between his desire to be good at his job and to be promoted, and his failure to care for the people who he was efficiently sending to their deaths.

What might a redefinition of practices of responsibility look like based on a negative model of wickedness? The negative model of culpability is articulated in criminal law in negligence, but this is regarded as exceptional to the subjective model of culpability, ${ }^{76}$ and there have been no prosecutions of officials in relation to systemic failures in response to child sexual abuse under this concept of negligence. One possible area of redefinition is in considering the implications of corporate harm-doing afresh, ${ }^{77}$ emphasising the link between corporate failure and harmful consequences, as shown by specific provisions for corporate liability in the Criminal Code (Cth). ${ }^{78}$ General principles of the Code articulated in Div 12 provide that:

This Code applies to bodies corporate in the same way as it applies to individuals. It so applies with such modifications as are set out in this

74 Augustine, The Confessions of St Augustine (Edward Pusey trans, Collier, 1961) VI, iii, 4.

75 The flexibility of the golden mean highlights the need for malleability in fault terms. This was expressed by Aristotle's arguments about the different food needs of different people with different body sizes. For Aristotle, the golden mean is relative. Aristotle, above n 73, II, 1106b5-1108: 'In this way, then, every knowledgeable person avoids excess and deficiency, but looks for the mean and chooses it - not the mean of the thing, but the mean relative to us'.

76 Penny Crofts, Wickedness and Crime: Laws of homicide and malice (Routledge, 2013).

77 Fisse and Braithwaite have developed a concept of 'reactive fault'. On this basis, harm caused, whether purely accidental or not, would be treated as a potentially serious offence until the company established otherwise. This reverses the onus of proof, requiring corporations that caused or threatened a proscribed harm to takes its own disciplinary and rectificatory measures, which would then be assessed by the courts in terms of the adequacy of the measures taken: Brent Fisse and John Braithwaite, Corporations, Crime and Accountability (Cambridge University Press, 1993). This approach to culpability is based on harmful consequences being sufficient in and of themselves to justify culpability. It has precedent in criminal law, see Fletcher, above n 34. The emphasis upon harmful consequences is central to Card's definition of wickedness: Claudia Card, 'The Atrocity Paradigm revisited' (2004) 19(4) Hypatia 212; Claudia Card, The Atrocity Paradigm: a theory of evil (Oxford University Press, 2002).

78 Criminal Code (Cth) Pt 2.5, Corporate Criminal Responsibility,. 
Part, and wish such other modifications as are made necessary by the fact that criminal liability is being imposed on bodies corporate rather than individuals.

The Code provides provisions for subjective culpability in s 12.3 that conceptualises failure as fault. This extension of concepts of intention, knowledge or recklessness is expressed in s 12.3(c) and (d):

(c) proving that a corporate culture existed within the body corporate that directed, encouraged, tolerated or led to non-compliance with the relevant provision; or

(d) proving that the body corporate failed to create and maintain a corporate culture that required compliance with the relevant provision.

Here failure is described in active terms, where corporate culture either encourages non-compliance or fails to ensure compliance. ${ }^{79}$ It covers the more elusive (and more likely situation in corporations) of "implicit authorisation where the corporate culture encourages non-compliance or fails to encourage compliance'. It is a means of holding corporations liable on the basis that;

$[\mathrm{T}]$ he policies, standing orders, regulations and institutionalised practices of corporations are evidence of corporate aims, intentions and knowledge of individuals within the corporation. Such regulations and standing are authoritative, not because any individual devised them, but because they have emerged from the decision making process recognised as authoritative within the organisation. ${ }^{80}$

The section allows the prosecution to lead evidence that the company's unwritten rules tacitly authorised non-compliance or failed to create a culture of compliance. It would catch situations where, despite formal documents appearing to require compliance, the reality was that noncompliance was expected. ${ }^{81}$ This would cover Hayes' claims that he believed his duty was to report abuse to the TCEO rather than police. This concept of corporate culture is apposite to the failure of the TCEO (and the regulator) to ensure compliance and builds upon the negative model of wickedness where failure and ignorance is culpable. Here, the emphasis is upon failure: the failure to live up to expectations of the community of a reasonable company. The negative model of wickedness holds out the possibility of conceiving of corporate failure as culpable and will often be more appropriate to apply to corporations than the positive model of wickedness. It provides an example of a redefinition of responsibility

79 Section 12.3(6) 'corporate culture' means an attitude, policy, rule, course of conduct or practice existing within the body corporate generally or in the part of the body corporate in which the relevant activities takes place.

80 Stewart Field and Nico Jorg, 'Corporate Manslaughter and Liability: Should We Be Going Dutch?' [1991] Criminal Law Review 156, 159.

81 Criminal Law Officers Committee of the Standing Committee of AttorneysGeneral, Model Criminal Code: Final Report December 1992, Ch 2: General Principles of Criminal Responsibility (Cth). See also Eric Colvin, 'Corporate Personality and Criminal liability' (1995) 6 Criminal Law Forum 1; Tahnee Woolf, 'The Criminal Code Act 1995 (Cth) - Towards a realist vision of corporate criminal liability' (1997) 21 Criminal Law Journal 257. 
practices that bypasses the criminal law focus upon individuals in attributions of blameworthiness and reinstates a link between (failure to) act and harmful consequences.

\section{ConClusion}

The Royal Commission hearings have demonstrated again and again systemic failure in response to child sexual abuse across a broad spectrum of institutions. The hearings have also demonstrated the failure of the criminal justice system to hold the vast majority of officials responsible for these failings. When reading the Royal Commission reports it is frustrating and distressing because there is a litany of failure, and yet we currently lack the normative and legal concepts to hold someone responsible. This failure to hold institutions responsible for systemic failures enshrines irresponsibility. It is also important to fix our response to organisations because we have become increasingly dependent upon complex organisations, at a time when the legal systems practices of responsibility have not evolved. We need to critically consider practices of irresponsibility.

This article has analysed criminal legal structures that are such consistent obstacles to ascribing responsibility in response to systemic failure that they can more be appropriately regarded as irresponsibility practices. The emphasis upon individual responsibility is inappropriate and insufficient in complex organisations. The division of labour demarcates specific tasks and jobs, so the outcomes are severed from the actor. Too many officials claim 'it is not my job', and this is accepted all too often by the criminal legal system. The requirement of subjective culpability exacerbates the division of labour as it is extremely difficult to establish subjective awareness in complex organisations, particularly higher up the hierarchy. And yet the upper echelons may well be responsible for the lack of awareness and ignorance of the staff at the frontlines. We should regard the dominance of individualised subjective culpability as irresponsibility practices that are patterned obstacles to holding officials and organisations responsible for failure. Veitch has argued that the organisation of irresponsibility can be so endemic that it results in 'the inability to have the question of responsibility raised at all'. ${ }^{82}$ We need to change the normative imagination so that failure can be regarded as sufficiently blameworthy to justify attributions of culpability to officials and organisations. Veitch has been described as a disappointed idealist. ${ }^{83}$ He attributes great power to the law in inscribing practices of irresponsibility. The flipside of this is that the law has great power to effectively redefine practices of responsibility.

82 Veitch, above n 4, 107.

83 Andrew Goldsmith, 'Seeing Red: Legal Indifference on a Field of Pain and Death' (2014) 34 Australian Journal of Legal Philosophy 228, 232. 